\title{
Kodaikanal an Emerging MICE Tourism Destination in Tamilnadu (India)
}

\author{
Premalatha P.N. \\ Professor and Head,Dept.of History and Tourism,Mother Teresa Women's University, \\ Kodaikanal-624101India
}

\begin{abstract}
Kodaikanal, apleasant hill station is on the upper part of the Palani Hills, an offshoot of the Western Ghats Mountain in Tamilnadu. It is one of the finest holiday destinations in the country which is still unharmed by the reckless urbanization and commercialization as seen in some of the other locations. It caters to the needs of all types of tourists with its natural attractions, salubrious climate and strong infrastructure. As a mass tourism destination, the arrival of both domestic and international tourists is increasing every year. Being a favourite tourist destination, Kodaikanal is fast gaining its place in the competition to become an ideal MICE destination in Tamilnadu. Most of the hotels provide facilities for conferences with modern technology and its natural attractions and pleasurable activities provide peace of mind. Business Conferences, meetings, seminars, family gatherings and functions held in the cool and invigorating hill environs ofKodaikanal as its backdrop is a memorable experience.
\end{abstract}

Keywords: Conference, Exhibition, Domestic Tourism, Incentive, Infrastructure, International Tourism

\section{INTRODUCTION}

Nowadays Corporate Bodies, Associations, and N.G.O's organize meetings, conferences, and exhibitions at exotic tourist destinations which include sightseeing, recreation, and shopping to encourage its members and their families and to boost up their efficiency. Realizing the benefits of it to business, this trend has gained popularity. MICE are the short form of Meetings, Incentives, Conferences and Exhibitions. It is a type of business tourism. It is a well-planned tour usually arranged for a special interest group for business purpose rather than an individual business traveller. Meetings involve product launch, cocktail functions, and special occasions like wedding, lunch and dinner meetings. Incentive tours are mostly for entertainment rather than business or professional. It is usually arranged for the employees to spend a vacation with the family in recognition of their performance or rewards the employees' effort. Conferences or Conventions are generally held for more than a day attended by hundreds of delegates for the purpose of exchanging business information or knowledge. If more than $40 \%$ of the delegates are from foreign countries, then the event is termed as an international conference or convention. Exhibitions are conducted for corporate leaders and business people for viewing the products and services of different business groups. MICE Tourism is an emerging concept and cosmopolitan and important cities are only considered as MICE destinations. Kodaikanal with its natural heritages and recognition as international tourist destination attracts considerable number of MICE tourists mainly incentive tourists. But it is not in the MICE map. There is no previous study also. Hence an attempt is made in this research to bring out the potentialities of MICE Tourism in Kodaikanal and its benefit to the hotels and the locals. After an introduction about MICE Tourism in India and in Tamilnadu, locational advantages of Kodaikanal and the infrastructure for MICE Tourism in select hotels are narrated. Data for this article have been collected through field visit, from the tourism office, hotels and from the official websites.

\section{INDIA}

India is one of the fastest growing destinations for conventions and meetings of all shapes and sizes. Ministry of Tourism, Government of India constituted India Convention Promotion Bureauto develop MICE Tourism. This is the only travel industry body with participation from the entire MICE industry, with representatives from state governments, airlines, tour operators, travel agents, professional conference organizers, hotels, event managers and educational institutions. Its main objectives are to promote India as a competent and credible MICE destination and to undertake a continuing program of creating better awareness of the role and benefits of MICE in the context of national objectives and to develop convention centres all over the country to make India the preferred destination of the world. The Bureau participates in travel conferences and also organizes road shows both at domestic as well as international locations to formalize the concept. There is a growth of inbound MICE tourists of India at the rate of 15 to 29 percent every year. The Draft Tourism Policy 2015 released by the Ministry of Tourism identified MICE as an important Tourism product and facilitate 
pre/ post leisure for them with an aim to extend their stay, motivate them to visit other locations and earn more foreign exchange from them. MICE Promotion Bureau with industry representation will be set up at the Centre and at the State / Destination level. In the Smart Cities, MICE facilities will be an integral component.

\section{TAMILNADU}

The state of Tamilnadu is taking proactive measures in promoting MICE Tourism in the state. A spectacular destination of ancient wisdom bestowed with the eternal grace of nature, Tamilnadu is being promoted as an enchanting destination for holidaying in southern India and tourism is a major contributor to the state's economy. More than 2.5 crore domestic tourists and 18 lakes foreign tourists visit the state every year. $30 \%$ of the international tourists visiting India also visit Tamilnadu. The state has been able to maintain impressive tourist arrivals and offers a relatively secure environment for business and leisure. Consistency in policies and a business-friendly approach has helped the State Government attracts a good investment in tourism. To increase the arrival of tourists to Tamilnadu and to appreciate its variety of attractions, the Government of Tamilnadu has initiated a number of schemes and launched marketing campaigns. Its marketing campaign of "Enchanting Tamilnadu: Experience Yourself" began in 2003-04 has been very popular and has given consistency and theme to the advertisement effort of the department. While "Enchanting Tamilnadu" summarizes the rich and varied tourism wealth of Tamilnadu, "Experience Yourself" strikes a chord with the tourists in India and abroad. The advertisement campaign is designed to represent core strength of tourism in Tamilnadu like its heritage, history, culture, spirituality and peace. Taking good care of tourists itself is a pull factor in tourism. Tamil Nadu has a strong industrial base, seaport and airports, star hotels, spas, stadium, ayurvedic centers and recreation facilities. It has wonderful amenities for MICE Tourism. It will attract large segments of Businessmen, Industrialists, Investors, Specialists, and Artists etc. to make Tamil Nadu as a hub for their national and international activities. As per the senior official at the Tamilnadu Tourism Development Corporation,Chennai and Coimbatore are rising as popular conference centers. MICE tourists have a potential to become high spending tourists. Tamilnadu Trade Promotion Organization has constructed a colossal convention centre with the state of art amenities in the extensive Chennai Trade centre campus. It is close to the International Airport. There are a few five star hotels in close locality. Chennai Convention Centre in cool and green environ perfectly refreshes the mind and balancing blends it with the business while holding a conference or conducting an event. It provides an ideal setting for a meeting with friends or colleagues. Presence of good information technology, excellent connectivity, and good infrastructure are the major advantages for MICE Tourism.

\section{KODAIKANAL}

Kodaikanal, a hill station at the Palani Hillin Tamilnadu is known for its naturalheritages, very rare and scarce plants and animals of India. The hill consists of a span of 2068 sq.km land is known for the varied types of flora and fauna and natural beauty. The salubrious climate is its added attraction. It varies from moderate to quite cool. During March to May, the temperature is between $11^{\circ} \mathrm{C}-20^{\circ} \mathrm{C}$ and from December to January it is between $8.3^{\circ} \mathrm{C}-17.3^{\circ} \mathrm{C}$ and night temperatures sometimes goes down to ice-cold and thin ice can be seen on the lake boundaries. The entire hill is popularly addressed as Kodaikanal. Kodaikanal town is situated 2133 meters above sea level. It is $100 \mathrm{~km}$ from Dindigal and $125 \mathrm{~km}$ away from Madurai. Today more than 50\% of the town's population is dependent on the industry for survival. Many foreign tourists prefer to spend a few days in the hill station in their plan of stay in India. In 1982, there were 3, 79,846 touristsvisited the hill which increased to 5, 79,620 in 1987. During the year 2014, there were 46, 00,193 domestic and 57068 international tourists visited. Apart from that every day thousands of excursionists visit. It has many picnic and trekking spots. Tourist spots only can be MICE hotspot. The sophistication of modern event organization combined with the salubrious climate, scenic beauty, and cost effectiveness make Kodaikanal a preferred destination for MICE Tourism.

\section{HOTELS WITH MICE FACILITIES}

MICE Tourism is an attractive proposition for the hospitality sector. Various star hotels /resorts like The Carlton, Sterling Valley View Hotel, Sterling Holidays Lake View Hotel, Sterling Resort Hotel, Kodai International,S.V.International, Park View, Sabari International, Hill Country, Kodai Resort Hotel, Green Acres Resort, Highland Parade, JC Residency etc. provide world-class conference facilities. Till date, they have hosted many national and international gatherings. As most of the luxury hotels have come up with a number of facilities to host business meetings and tour packages to explore the beauty of Kodaikanal, MICE Tourism is now fast growing here. The convention hall of the Carlton Hotel has always been a favorite venue for meetings and conferences of top business officials and government officials for over four decades.

Of all the hotels, The Carlton, in Kodaikanal is popular among MICE tourists. The peaceful environment of The Carlton provides an apt venue for business conferences, seminars, and events of all 
descriptions. The Carlton, spread over 3.75 acres, located in front of the Kodai Lake, and surrounded by nature at its very best is within walking distance of most of the scenic and sightseeing spots. KodaiLake is one of the main attractions for the tourists of Kodaikanal. The lake is a big one stretching over 60 acres and bordered by fine road of $5 \mathrm{~km}$ length.Boating services are available with Kodaikanal Boat Club, T.T.D.C boats and Carlton boats on hire for hours. There are luxury boats also. Rescue parties are posted nearby for emergency situations.

The very location of this hotel facing such a wonderful lake is an added attraction. The Carlton is an epitome of beauty, serenity, and the colonial charm. The hotel is well planned and constructed to aesthetically blend with the surroundings; the property has beautifully landscaped gardens with a wide selection of flowers, plants, and shrubs. Nature in abundance, coupled with their excellent state of the art conference facilities, conjure up the magic formulae for fresh and creative business sessions on the one hand, while the innumerable recreational sessions relax and stimulate mind and body on the other. With its regal aura of exclusiveness, The Carlton is aptly called the Capital of Kodaikanal. The Carlton holds the distinction of being Kodaikanal's only five-star hotel. Spacious and luxurious accommodation is the trademark of The Carlton. There are ninety-one stylish and comfortable rooms, including five suites and three charmingly built cottages. The restful ayurvedicmassage and the other treatments provided by the experts' masseur and herbalists at the spa lend a fantastic touch to the vacation. The Carlton Club is the center of entertainment for the hotel guests and has activities for every age group.

There are three conference halls; Wellington Conference Hall is designed for corporate meetings. It can accommodate 30 people in theatre seating, 25 people in classroom seating, 15 people in U-shaped seating and 20 people in cluster seating. The dimension of the hall is $25.6 \mathrm{ft}$ X $21.6 \mathrm{ft}$. X $6.9 \mathrm{ft}$. Cumberland Hall can accommodate 125 people in theatre seating, 50 people in classroom seating, 50 people in U-shaped seating, 50 people in E-shaped seating and 72 people in cluster seating. The dimension of the hall is $50 \mathrm{ft}$. X $22.9 \mathrm{ft}$. X 7.9 $\mathrm{ft}$. A hall is with all essential facilities for organizing hassle-free events. The Silver Oak conference hall has a capacity of 125 people.This hotel is ideal for Dealer Conferences, Annual Sales meetings, Top Management Training Programmes, Strategic Board meetings, Brain Storming Corporate Sessions, Workshops, and Seminars. Their Banquets and Events Team lend its expertise in ensuring the success of the event, down to the last detail. All comprehensive conference equipment is provided by the hotel from markers, to a flip chart to a projector to paper pads and pencils. The Carlton events team specializes in organizing innovative themes for conferences. Ranging from sober to wild, exotic to contemporary, meticulous planning and unwavering attention makes these theme conferences memorable. It is a favorite venue for top businessmen. Amidst tranquility, it is suitable for conducting business with style. Interspersing the work sessions with soothing activities that recharge the creativity and concentration. Besides business trips, guests can explore and enjoy many wonders of nature. Participants will get the perfect balance between work and holidays. The excellent lake with boating facilities facing the hotel gives the guests a refreshing escape from the meetings and conferences. There are a lot of other activities to do after the academic deliberations such as spa, steam room, beauty parlor, massages, air hockey, pool table, table tennis, board games, library, foosball, billiards, badminton, boat house, cycling, table tennis, chess, ayurvedic body massage etc. and the participants fully relax after the academic sessions. Also, the clients can indulge in a variety of experiences including fine dining, cultural shows, soft adventure, sightseeing shopping and fun. A number of participants play chess and tennis in the evenings after the exhausting academic sessions. While some participants would go away sightseeing to places like Silver Falls, others could be seen cycling around the Kodai Lake. Its proximity to lake makes the stay more interesting. As most of the expenses are company paid they seek the best.

During the year 2007-8, 11869 occupants from 156 companies/ business firms utilized the hotel as MICE tourists and it was 169 companies and 12989 occupants in 2010-11. Year after year the number increases. The most preferred month for such programs is April followed by August, the least preferred month is December followed by November. So winter season is not in preference for many. The statistics from The Carlton show that annually, of the occupants more than 10,000 people are represented by the Corporate Companies for some events or other. Corporate companies conduct their annual meets regularly in this hotel combining business and tour. A conference will surely be an experience of a lifetime.

Another venue providing up to the par facilities for MICE events is Sterling. Sterling Holiday Resort serves as a perfect MICE venue. Sterling Valley view is an ideal venue for conferences, seminars, and workshops. The 50 feet x 50 feet Business Hall has seating capacity for up to 300 people (seated theatre-style), with a 250-watt 4-speaker sound system and a 6 feet x 6 feet projection screen. Its MICE packages are designed to increase overall employee well-being by whisking them away to scenic locales. Equipped with state of the art conference facilities it is capable of taking care of the clients business communication needs. Today'sstressful businessmenneed many thingsother than just fresh air, the hotel offers complete MICE solutions right from airport transfers to accommodation, banquets to evening entertainment and sightseeing to just about anything else the client may need to make their MICE event a smashing success. Created for the benefit of employer and employees alike, Sterling's MICE packages offer great value for money. Added to that its well-groomed and 
well-trained staff, pre - tour and post-tour packages and other packages suitable for their families make the event memorable.

Hotel Kodai International offers the best in the end to end solutions for all MICE tour needs with an excellent ambiance and atmosphere to suit the taste and expectations of the tourists. It has four conference halls namely Coakers Hall- 1850 sq.ft, Bryant Hall-1326 sq.ft, Moier Hall- 572 sq.ftand Law Hall 1719 sq.ft. Each hall can be arranged in Broad room style, Classroom style, U-shape style, Banquet style and Theater style. Keeping in sync with the overall mood of the place, the hall has a traditional design with local paintings and murals lining the walls. It has an in-built audio system. The hotel also offers secretarial services and banquet facilities. An open area adjoining the lobby has been fitted with disco lights and a sound system and serves as a stage. It lies between the lobby and the lawns, making it ideal for organizing theme parties, cultural shows, and performances. In addition organized outdoor activities are conducted by specially trained staff. It includes sightseeing, picnics, treks and hikes, cycling and horse riding. The library is also available.

Sabari Resorts has extensive conference, exhibition and business resources, accommodating from 20 up to 200 guests. Its conference halls Windsor and Westminster are marveloushalls to conduct celebrations, private receptions, parties and exclusive meetings. It offers a wide-ranging setting of multifunction locations, offering the highest standards in meeting facilities within modern and stylish venues. From glittering product launches to gala dining, photo shootings and fashion shows, highly personalized service ensures most memorable gatherings, plus excellent catering facilities.

MICE Tourism is always considered lucrative by hoteliers because the revenue generated by this segment is four to eight times more than the leisure travellers. Travel as an incentive tool for the organization's sales executives, dealers has no limits. At one level, it's a holiday that enables the executive to relax and revitalize. At another, it is a reward for excellence, a part on the back that inspires the team.

\section{CONCLUSION}

Incentive travel segment is the most popular one in Kodaikanal. Employees achieving smaller targets get to enjoy vacations at domestic locations and larger targets are rewarded with foreign travel. One of the main reasons why corporatesector spends on this segment is that an executive traveling abroad whether to attend a conference /exhibition or even on a holiday is bound to strike business opportunities during the visit. A stay in Kodaikanal is a prize for the winners of various competitions organized by companies or business firms. It works wonders at all levels. For the management, it is an opportunity to convey appreciation and to recognize high achievers in ways that will be cherished for a lifetime. It is culturally acceptable, environmentally sustainable and economically feasible. For the locals it generates jobs and more income. This eco friendly tourism develops Kodaikanal as an all season, all budget tourist destination without disturbing the natural beauty of interior forests.

\section{REFERENCES}

[1]. http://www.sbstours.in/mice.html retrieved on $14 / 04 / 2017$.

[2]. India Inbound MICE Tourism Trends and Opportunities, May 2016, MRSS India.com A Majestic MRSS Company http://indianbusiness.nic.in/newsdesign/upload/india-inbound-Report-MICE.pdf retrieved on $12 / 05 / 2017$

[3]. http://www.indiatourismecatalog.com/india_mice_tourism/mice_tourism_tamil_nadu.htm

[4]. Premalatha, P.N "Hop On Hop Off Tour in Chennai: A New Marketing Strategy of Tamilnadu Tourism Development Corporation" in Dileep M.R.(ed) International Marketing in Tourism(New Delhi:Anmol Pub., 2011) 338-347.

[5]. Tourism And Culture Department Tourism Policy Note 2011-2012, Government of Tamilnadu.

[6]. Tourism, Culture and Religious Endowments Department Tourism Policy Note 2016-2017 Demand No.29, Government of Tamil Nadu http://www.tamilnadutourism.org/pdf/Policynoteenglish2016-17.pdf retrieved on $12 / 05 / 2017$

[7]. http://harshamitra.com/portfolio/asi-state-conference-at-kodaikanal/ retrieved on 17/05/2017

[8]. http://www.kodaiinternational.com/mice retrieved on $17 / 05 / 2017$.

[9]. http://www.meetings-conventions.com/meetings-facilities/kodaikanal-india/hotels retrieved on 20 /04/2017

[10]. Mathew, K.M., A Handbook of the Anglade Institute of Natural History, Shembaganur. (Trichi: St.Joseph's College, 1994)

[11]. http://perfectindianholidays.com/mice.html retrieved on 19/04/2017

[12]. http://www.carlton-kodaikanal.com/meetings-events.html retrieved on $20 / 05 / 2017$

[13]. http://mice.sterlingholidays.com/ retrieved on $20 / 05 / 2017$

[14]. http://www.kodaiinternational.com/mice retrieved on $14 / 05 / 2017$

[15]. http://www.hillcountry.in/kodai/offers-packages/mice/ retrieved on 15/05/2017

[16]. http://www.hillcountry.in/kodai/facilities/ retrieved on 19/05/2017 
[17]. http://harshamitra.com/portfolio/asi-state-conference-at-kodaikanal/ retrieved on 19/05/2017

[18]. http://www.kodaihotelparadiseinn.com/conference-hall.html retrieved on 17/05/2017

[19]. http://tourism.gov.in/sites/default/files/tamilnadu.pdf retrieved on 18/05/2017.

[20]. http://www.tamilnadutourism.org/pdf/tour_e_pn_2014_15.pdf retrieved on 11 /04/2017. 